\title{
SUNY College of Environmental Science and Forestry Humanitarian Engineering: Small Scale College Components and Analysis
}

\author{
Thomas Decker \\ Undergraduate Student, Dept of Engineering \\ SUNY College of Environmental Science and Forestry \\ Syracuse, NY 13210 \\ DeckerThomasJ@gmail.com
}

\author{
Theodore Endreny \\ Professor \& Chair, Dept of Engineering \\ SUNY College of Environmental Science and Forestry \\ Syracuse, NY 13210 \\ Te@esf.edu
}

\begin{abstract}
The State University of New York College of Environmental Science and Forestry (SUNY-ESF) enrolls approximately 1900 bachelor students and 600 master's and PhD students focusing on the science and engineering of environmental sustainability. To satisfy student and employer interests in sustainable international development, ESF has developed a humanitarian engineering program. The program includes theoretical and field based course work, trips abroad, student organizations, and the establishment of the National Academy of Engineering Grand Challenges Scholar's Program (NAE GCSP). This manuscript describes the history, components, challenges, best practices, lessons learned, case studies, and outcomes of ESF's small-scale yet successful humanitarian engineering program.
\end{abstract}

Index Terms - education, humanitarian engineering, international development, small scale university

\section{INTRODUCTION}

Experiential learning and project based curricula are used in many undergraduate and graduate programs at the State University of New York (SUNY) College of Environmental Science and Forestry (ESF) to help the students reach the school's challenge, summarized as "Improve your world". The ESF department of Environmental Resources Engineering created a humanitarian engineering program that responds to the ESF challenge through curricular and extra-curricular activities. Students can engage the humanitarian engineering program in several ways, ranging from formal completion of ESF's National Academy of Engineering (NAE) Grand Challenges Scholars Program (GCSP, http://www.esf.edu/ere/undergraduate/gcsp/default.htm), to much smaller commitments, including single events with courses or clubs.

The ESF NAE GCSP has 5 curricular components that are structured to prepare students to engineer a better world: 1) doing it through projects, practicums, and research; 2) learning it through interdisciplinary curriculum that combines engineering with non-engineering perspectives; 3 ) sharing it through global outreach to areas where the need is greatest; 4) creating it through entrepreneurial activities that lead to financing and distribution of the engineering solution(s); and 5) teaching it through service learning activities. The "it" of the ESF NAE GCSP is one or more of the fourteen NAE grand challenges in engineering, which lie within 4 broad themes: a) energy and environment (e.g., manage the nitrogen cycle), b) health (e.g., engineer better medicines), c) security (e.g., restore urban infrastructure), and d) learning and computation 
(e.g., engineer the tools for scientific discovery). The ESF program in humanitarian engineering is designed to allow students to engage at the level of a single course or non-course activity, or to engage the ESF NAE GCSP and complete a project or research experience on one of the NAE grand challenges as well as four other curricular requirements.

\section{Program BaCkground}

ESF has been training students in humanitarian engineering for decades, with faculty mentoring students to engage programs such as the United States Peace Corps, the United Nations Earth Summit, the Millennium Development Goals, as well as many other religious and secular efforts. Participating in the NAE GCSP allows ESF to leverage a large, established program to counterbalance the department of Environmental Resources Engineering's (EREs) relatively small program size, with fewer than 160 undergraduate students and 7 faculty in the department. The entire ESF campus has 1700 enrolled undergraduates and 120 full-time faculty, who also mentor approximately 500 graduate students through the Ph.D. The ESF college and ERE department are dedicated to training students for careers in professional practice and research, and courses are offered in classrooms, labs, and field sites to train students how to translate theory into practice.

The ESF program in humanitarian engineering is incorporated into an undergraduate curriculum which emphasizes practical professional training in capstones and courses and adheres to best practices in pedagogy. The capstone courses and the course-based practical professional training uses NAE strategies to partner with industry, agencies, and community groups to prepare globally competitive graduates ${ }^{1}$. The pedagogical best practices use six recent findings in engineering education to assist students reach ambitious engineering program goals ${ }^{2}$, including ESF's, "Improve your world". These best practices are listed below along with a statement of their curricular goal and summary of how they are achieved:

TABLE I

BEST PRACTICES OVERVIEW

\begin{tabular}{|c|l|l|l|}
\hline Best Practice & \multicolumn{1}{|c|}{ Description } & \multicolumn{1}{c|}{ Goal } & \multicolumn{1}{c|}{ Method } \\
\hline & $\begin{array}{l}\text { Context and } \\
\text { Continual } \\
\text { Integration } \\
\text { Promotes Transfer } \\
\text { of Knowledge \& } \\
\text { Skills }\end{array}$ & $\begin{array}{l}\text { Continually engage } \\
\text { students in integration of } \\
\text { knowledge and skills } \\
\text { across context and time on } \\
\text { tasks the students' value }\end{array}$ & $\begin{array}{l}\text { Acquire component knowledge and } \\
\text { skills and practice them to the point } \\
\text { when students can combine them } \\
\text { fluently, then use them when } \\
\text { appropriate. }\end{array}$ \\
\hline
\end{tabular}




\begin{tabular}{|c|c|c|c|}
\hline 2 & $\begin{array}{l}\text { Early Exposure } \\
\text { Lays the } \\
\text { Foundation for } \\
\text { Future Learning }\end{array}$ & $\begin{array}{l}\text { Introduce engineering } \\
\text { students to design in the } \\
\text { 1st year to expose them to } \\
\text { thinking like an engineer } \\
\text { and motivate learning }\end{array}$ & $\begin{array}{l}\text { Use design courses each year to } \\
\text { reinforce that design is open ended } \\
\text { and engineering challenges extend } \\
\text { beyond domains (i.e., sponsored by } \\
\text { agencies, NGOs, communities). The } \\
\text { first year is more conceptual, the last } \\
\text { year is more technical. Develop skills } \\
\text { to: structure ill-structured problems } \\
\text { and decompose problems; implement } \\
\text { systems perspectives; identify } \\
\text { parameters and constraints; work in } \\
\text { teams }\end{array}$ \\
\hline 3 & $\begin{array}{l}\text { Meaningful } \\
\text { Classroom } \\
\text { Engagement Leads } \\
\text { to Deeper Learning }\end{array}$ & $\begin{array}{l}\text { Enhance learning with } \\
\text { deliberate practice coupled } \\
\text { with targeted feedback in } \\
\text { and out of the classroom, } \\
\text { providing the opportunity } \\
\text { to apply concepts or } \\
\text { principles, and consider } \\
\text { alternative approaches or } \\
\text { designs. }\end{array}$ & $\begin{array}{l}\text { To achieve realistic practice and } \\
\text { feedback then accomplish meaningful } \\
\text { engagement in many ways, including: } \\
\text { peer instruction in conceptual } \\
\text { questions; realistic case study } \\
\text { problems connecting theory and } \\
\text { practice; problem based learning } \\
\text { using analytical and integrative } \\
\text { thinking; flipped or inverted } \\
\text { classrooms; collaborative and } \\
\text { cooperative learning }\end{array}$ \\
\hline 4 & $\begin{array}{l}\text { Reflection } \\
\text { Connects Thinking } \\
\text { and Doing }\end{array}$ & $\begin{array}{l}\text { Continually interweave } \\
\text { thinking and doing to } \\
\text { capture the meaning of } \\
\text { learning experiences and } \\
\text { establish structured } \\
\text { reflection }\end{array}$ & $\begin{array}{l}\text { Structure reflection with low stakes } \\
\text { writing and mathematical } \\
\text { assignments (i.e., focus on concepts, } \\
\text { not correcting for writing or } \\
\text { mathematical errors); ask students to } \\
\text { express what they are learning and } \\
\text { how it connects with what they } \\
\text { already know, and how they might } \\
\text { use the knowledge in the future; } \\
\text { create e-portfolios allowing students } \\
\text { to assemble and showcase evidence } \\
\text { of learning }\end{array}$ \\
\hline
\end{tabular}




\begin{tabular}{|c|c|c|c|}
\hline 5 & $\begin{array}{l}\text { Metacognition } \\
\text { Supports the } \\
\text { Development of } \\
\text { Lifelong Learning } \\
\text { Skills }\end{array}$ & $\begin{array}{l}\text { Students continue to learn } \\
\text { independently and are } \\
\text { disabused of the } \\
\text { presumption that engineers } \\
\text { work only on problems } \\
\text { that can be solved using } \\
\text { memorized facts and } \\
\text { procedures }\end{array}$ & $\begin{array}{l}\text { Engage students in metacognition, } \\
\text { defined as the process of reflection } \\
\text { and directing one's own thinking. } \\
\text { Self-directed learning requires } \\
\text { students: assess the task at hand, } \\
\text { including goals and constraints; } \\
\text { evaluate their own knowledge and } \\
\text { skills including strengths and } \\
\text { weaknesses; plan their approach in a } \\
\text { way that accounts for the current } \\
\text { situation; apply various strategies to } \\
\text { enact the plan and monitor their } \\
\text { progress; reflect on the degree to } \\
\text { which their current approach is } \\
\text { working so that they can adjust and } \\
\text { restart the cycle as needed }\end{array}$ \\
\hline 6 & $\begin{array}{l}\text { Experimental } \\
\text { Learning } \\
\text { Opportunities } \\
\text { Connect Theory \& } \\
\text { Practice in } \\
\text { Authentic Settings. }\end{array}$ & $\begin{array}{l}\text { Create an educational } \\
\text { environment that weaves } \\
\text { the connections back and } \\
\text { forth across the formal and } \\
\text { experiential curriculum }\end{array}$ & $\begin{array}{l}\text { Engage students in experiential } \\
\text { learning activities, such as co-ops or } \\
\text { service learning, so that they apply } \\
\text { what they have learned before } \\
\text { entering the workforce }\end{array}$ \\
\hline
\end{tabular}

Students engaged in the ESF humanitarian engineering program employ these best practices while being principally motivated by the chance to help address critical global engineering and development challenges that involve the security of food, water, hygiene, and energy resources from different cultural perspectives.

\section{COMPONENTS}

The course and non-course activities that students can engage in through the ESF program in humanitarian engineering are structured within the five standard NAE GCSP curricular areas of: 1) project or research experience; 2) interdisciplinary engineering, otherwise known as engineering+; 3 ) entrepreneurship; 4) the global dimension; and 5) service learning. The specific course and non-course activities in each of these curricular areas are listed in Table 1. This list includes options for students to identify equivalent experiences.

TABLE 2

COURSE AND NON-COURSE OPPORTUNITIES

\begin{tabular}{|c|c|c|}
\hline Curricular Requirement & Course Activity & Non-Course Activity \\
\hline $\begin{array}{l}\text { 1. Project or } \\
\text { Research Activity }\end{array}$ & $\begin{array}{l}\text { Optional } \\
\text { ERE 498, Research Problems in } \\
\text { Environmental Resources } \\
\text { Engineering, ERE 597, Research } \\
\text { Methods for ERE }\end{array}$ & $\begin{array}{l}\text { Required } \\
\text { Choose } 1 \text { of the following: } \\
\text { ESF Honors Program; Participate in } \\
\text { a NSF REU; Participate in the } \\
\text { research and development of an } \\
\text { Engineers Without Borders project; } \\
\text { Participate in an ESF Fink or Rosen } \\
\text { Fellowship sponsored research } \\
\text { project; Equivalent experience }\end{array}$ \\
\hline Curricular Requirement & Course Activity & Non-Course Activity \\
\hline
\end{tabular}




\begin{tabular}{|c|c|c|}
\hline $\begin{array}{ll}\text { 2. Inter-Disciplinary } \\
\text { Curriculum, } \\
\text { Engineering+ }\end{array}$ & $\begin{array}{l}\text { Required } \\
\text { Choose } 1 \text { of the following: } \\
\text { ERE } 275 \text { Ecological Engineering; } \\
\text { ERE } 412 \text { River Form and Process; } \\
\text { ERE } 496 \text { Humanitarian Engineering } \\
\text { for Development Workers; ERE } 496 \\
\text { Hydrology in a Changing Climate } \\
\text { presentation on climate change } \\
\text { analysis) }\end{array}$ & Equivalent experience \\
\hline Curricular Requirement & Course Activity & Non-Course Activity \\
\hline 3. Entrepreneurship & $\begin{array}{l}\text { Choose } 1 \text { of the following: } \\
\text { ERE } 519 \text { Green Entrepreneurship } \\
\text { Or any equivalent course }\end{array}$ & $\begin{array}{l}\text { Choose } 1 \text { of the following: } \\
\text { Develop a business plan through the } \\
\text { Syracuse University Department of } \\
\text { Entrepreneurship and Emerging } \\
\text { Enterprises; Develop a business } \\
\text { plan through the Green Campus } \\
\text { Initiative's Student Sustainability } \\
\text { Fund; Develop a business plan } \\
\text { through the Yum! Sustainability } \\
\text { Challenge; Develop a business plan } \\
\text { through the D-Prize; Develop a } \\
\text { business plan through the GrabCAD } \\
\text { challenges; Equivalent experience }\end{array}$ \\
\hline Curricular Requirement & Course Activity & Non-Course Activity \\
\hline $\begin{array}{ll}\text { 4. } & \text { Global } \\
\text { Dimension }\end{array}$ & $\begin{array}{l}\text { Choose } 1 \text { of the following: } \\
\text { ERE } 496 \text { Appropriate Technology for } \\
\text { Developing Countries; ERE } 496 \\
\text { Humanitarian Engineering for } \\
\text { Development Workers; ERE } 311 \\
\text { Ecological Engineering in the } \\
\text { Tropics; FOR } 523 \text { Tropical Ecology; } \\
\text { GEO 374 Environment and } \\
\text { Development in the Global South }\end{array}$ & $\begin{array}{l}\text { Choose } 1 \text { of the following: } \\
\text { Participate in and report on a club } \\
\text { (e.g., Engineers Without Borders) } \\
\text { or conference pertaining to } \\
\text { international development; } \\
\text { Participate in and report on a study } \\
\text { abroad program; Participate in and } \\
\text { report on Operation Wallacea; } \\
\text { Participate in and report on the } \\
\text { Engineering for Change's } \\
\text { programs; Equivalent experience }\end{array}$ \\
\hline Curricular Requirement & Course Activity & Non-Course Activity \\
\hline 5. Service Learning & $\begin{array}{l}\text { Choose } 1 \text { of the following } \\
\text { ERE 489, Engineering Planning and } \\
\text { Design; An equivalent course } \\
\text { required of ESF students regarding } \\
\text { service learning }\end{array}$ & $\begin{array}{l}\text { Choose } 1 \text { of the following: } \\
\text { Participate in and report on the } \\
\text { service learning activities in the } \\
\text { annual EPA Campus RainWorks } \\
\text { Challenge Team; Participate in and } \\
\text { report on the service learning } \\
\text { activities in the EWB, ERE, } \\
\text { NYWEA, and/or AWMA clubs on } \\
\text { campus; Participate in and report on } \\
\text { the service learning activities in the } \\
\text { local Alpha Phi Omega or Alpha Xi } \\
\text { Sigma service and honor } \\
\text { fraternities; Equivalent experience }\end{array}$ \\
\hline
\end{tabular}


The list of options in Table 2 demonstrates the opportunities students have to take various courses related to international development, humanitarian engineering, and service learning that can be applied to their major of study. This table of options was developed through collaboration with NAE GCSP, the work of ESF's EWB chapter, and opportunities through Operation Wallacea, the EPA, and many other programs. All of the courses that are offered through the NAE GCSP at ESF had been regularly offered at ESF, taught by a combination of full time and visiting faculty, funded by the Provost.

One such course listed under Global Dimension, ERE 311: Ecological Engineering in the Tropics focuses on ecological and environmental issues in Costa Rica. Students build core knowledge on ecological engineering principles at the beginning of the semester and practice the concepts while on a weeklong trip to the country. The course is made possible through a partnership with Rancho Mastatal, a Costa Rican sustainable learning center that facilitates the study and creation of ecological engineering designs, including appropriate technologies and permaculture approaches for the sustainable delivery of water, food, energy, and health resources. Rancho Mastatal was founded by Tim O'Hara and his wife Robin and they help support the in country component of the course with lodging, food, and Costa Rica expertise. Throughout the year the ranch holds workshops in organic gardening, permaculture, and sustainable construction to name a few. The ranch also has the ability to host graduate students of the ERE department and support their research efforts. The connection with the ranch began in spring 2013 with continued collaboration throughout the year. The ERE 311 course allows students to combine the first three of the GCSP curriculum components; learn it, do it, and share it.

Additional courses under the Global Dimension are a 1 credit seminar titled ERE 496, Appropriate Technology in Developing Countries, and a 3 credit course titled ERE 496, Humanitarian Engineering for Development Workers, which gives students exposure to international development and issues relating to water, food, energy, and hygiene security. The success of these courses propelled the development of the NAE GCSP at ESF and provides theory and engineering application to the problems present in marginalized communities. In order to establish these courses, the ESF Provost agreed to provide funds for a visiting professor. To host workshops within the courses, EWB members wrote grant applications for alternate sources of funding. The main source was from a student club on campus that runs what is named the Student Sustainability Fund.

Students can use non-course activities such as service learning and club activities to expand their course-based learning or as a substitute for course-based activities when satisfying the NAE GCSP curricular areas. In these non-course activities the ESF Engineering for a Sustainable Society (ESS) and ESF Engineers Without Borders (EWB) student chapters play a large role. Participation in the ESS/EWB club empowers students to follow their interests and become practicing engineers with guidance from mentors and professors. Students within the club can pursue research credit or credit through ESF's Honors Program to receive academic recognition. The ESS/EWB club provides a range of opportunities with projects in New York, Honduras, Peru, Haiti, and Guatemala. To fund each of these projects, students ask for contributions from local engineering firms and Rotary International Chapters and fill out grants through large companies, societal organizations, and humanitarian aid agencies.

With the combination of the NAE GCSP program structure (Figure 1 in Appendix), courses related to humanitarian engineering, and the strong presence of the ESS/EWB club, ESF is able 
to provide many international development opportunities to the world's future engineers, even though it is a small university.

\section{Outcomes of ESF Humanitarian Engineering Program}

The ESF program in humanitarian engineering has impacted many constituents, including the participating students and faculty and the partner communities. The changes to the students include: 1) increased awareness and explicit statements of commitment; 2) increased enrollment in humanitarian engineering courses; 3) increased post-graduate volunteer experiences; 4) increased participation in non-traditional summer internships and research experiences; 5) increased interest in international and non-governmental organization jobs; 6) increased scope and membership in humanitarian engineering clubs; and 7) a broader engineering skillset associated with practicing skills in low resource, global environments. Each of these student outcomes is explained below.

1) There has been an increased interest in traveling to countries where ESF projects exist and becoming involved in such projects. The NAE GCSP and humanitarian engineering program has influenced students to recognize the importance of global engineering and has encouraged larger commitment to the course and non-course activities listed in Table 2. Beginning in fall 2014, the NAE GCSP has four student participants with over 80 undergraduate students participating in the activities supported by the program. More detailed information will be collected in the coming year.

2) The establishment of the humanitarian engineering program has made related courses more available to students and enrollment has risen from single digits to a range of 15-20 students in various courses. Enrollment is critical in funding decisions at small scale universities, making this outcome significant to the success of the program. Specific enrollment data is currently being compiled and will be available in the coming year.

3) Examples include joining professional EWB chapters, providing technical guidance in the role of a mentor, and having a greater awareness of existing projects in which they can participate. The humanitarian engineering program can provide pathways for post-graduate volunteering through a student's network established while accomplishing program requirements. Graduates of the program will have the ability to provide technical and research management insight to students currently in the NAE GCSP program if they so choose. Graduates can also become involved as a mentor with the ESS/EWB student chapter and volunteer their time to travel with a student team.

4) Within the past three years, ERE students have conducted engineering research, internships, and projects in Costa Rica, India, Nepal, South Africa, Peru, Haiti, Honduras, Mexico, Jamaica, Nicaragua, and Panama which shows the incredible inspiration that the humanitarian engineering program at ESF has upon students. In turn these projects are shared through presentations given by students at conferences and research spotlight events throughout the United States and their impact dispersed throughout the world (see Table 5).

5) Graduates that have participated in the program have moved on to volunteer or work with the World Bank, AmeriCorps, The Amazon Conservation Team, Engineers Without Borders chapters, WaterAid, and Peace Corps. With each year of the program's success, the list of ESF engineering graduates choosing these alternative routes increases. The program encourages students to network at conferences and gain contacts that may lead to future involvement in 
organizations such as those listed above. Alumni information and specific data of graduates involved in the program will be collected, but is not available at present.

6) Enrollment into the ESS/EWB club has been remarkable compared with other ESF clubs. ESS/EWB started in 2003 as 5 members and retained approximately 5-10 members each year. Starting in fall 2011, the club began to grow each consecutive year to the current membership at 80 students. For comparison to the program, ESF has two other aid-focused clubs on campus, the Society for Conservation Biology and the Global Student Embassy, that take students to Ecuador for development projects each year. The development of the humanitarian engineering program and associated clubs has been supported by significant student participation to create new organizations involved in humanitarian work. The establishment of these organizations shows a shift in student mindset that encompasses more of what is outside the United States and gives ESF a more global dimension.

7) Students are able to practice engineering using low tech appropriate tools such as clinometers and five gallon buckets and manual tools instead of power machinery. Students are also able to complete "back of the envelope" calculations to provide insight where high speed computer programs are not available. Having these "common sense" skills prove essential when practicing engineering in low resource and marginalized communities.

The changes to the faculty due to ESF's program in humanitarian engineering include: 1) increased effort by the department to recruit new faculty with international experience; 2) increased use of adjunct professors and visiting instructors to teach humanitarian engineering courses; 3) increased awareness of student interest in careers in humanitarian engineering, and hence adoption of the NAE GCSP and revamping of the curriculum; and 4) increased recognition of faculty as evidenced by a faculty finalist in the 2013 Institute of Electrical and Electronics Engineers Global Humanitarian Engineer of the Year award. The award recognized engineers who have had significant influence and accomplishments in the field of humanitarian engineering and is awarded every year at the Global Humanitarian Technology Conference. With the prospective increase in faculty involvement in the coming years, there will be more specific data and studies that address faculty recognition.

The changes to the communities due to ESFs program in humanitarian engineering include: 1) improved access to sustainable hydro-electric power in Dominica (December 2004); 2) improved environmental and community awareness of natural resources in Pico Bonito Park, Honduras (December 2005); 3) reduced mortality and entero-related diseases due to the development of a gravity fed water distribution system in Buena Vista, Honduras (2007-2014); 4) improved sanitation and ecological health due to the construction of a composting toilet in Marietta, NY (2013); 5) initial access to electricity via solar panels and hydro-electric in Abra Malaga, Peru (2012-2014); and 6) an increase in corporate and professional sponsorship of the ESF community and students. To better assess project sustainability and impact, the program will be utilizing EWB's new Planning, Monitoring, Evaluation, and Learning protocol to gather meaningful data.

The provision of electricity in Abra Malaga, Peru has benefited 150 community members, who now have access to electricity due to renewable energy installations. This electricity has allowed for light fixtures which elongate the work day and provide time for family members to practice reading and writing when no work can be done outdoors. The provision of a water supply in Buena Vista, Honduras has benefited 300 community members who now have access to clean, potable water which has decreased their likelihood of contracting water-borne illness. 
To learn more about the ESS/EWB organization and their projects please visit www.esf.edu/org/ess.

\section{Lessons Learned in Developing the ESF Humanitarian Engineering Program}

There have been several lessons learned about overcoming obstacles in the effort to develop the ESF program in humanitarian engineering, and some of these are likely unique to the small school experience. With each obstacle encountered, those surmounted are noted as program successes, while those obstacles that were not overcome resulted in program changes. The obstacles encountered include: 1) insufficient full-time faculty to operate the program; 2) insufficient student numbers to easily populate new humanitarian engineering clubs and courses; and 3) insufficient college revenues to fully fund student club projects.

The successes of overcoming the above listed obstacles for garnering student interest include: 2a) vibrant advertising of humanitarian clubs and courses; $2 b$ ) growth from 1 to 2 student clubs dedicated to humanitarian engineering; 2c) recruitment and inclusion of non-engineering students from complimentary programs at ESF in departments of environmental and forest biology (EFB), landscape architecture (LSA), and forestry and natural resources management (FNRM), as well as from the interdisciplinary major in environmental science and health. Even with these successes, changes are planned to improve the program

With respect to the first and third obstacle, there was a shift from full time faculty to adjunct faculty to compensate for budget shortfalls. Limited funding leads to the inability to attract and acquire needed engineering professors to assist in running the program. Current engineering staff members are occupied with teaching required coursework, coordinating research and recruiting new students. A solution to this issue has been the hiring of adjuncts from a large engineering community, such as professional chapters of ASCE, EWB, and IEEE and many Rotary International clubs and past Peace Corps volunteers that have a passion for international development. The adjuncts are assigned responsibility to create course content, plan hands on learning activities, and may have opportunities to travel with student design teams. At a time, the program has one to three visiting professors, both paid and volunteer, for solely a semester or multiple years.

With respect to the third obstacle, a planned change for the ESF program in humanitarian engineering include introducing design projects into the sophomore and junior year curriculum. For example, in the 1 credit discussion course ERE 496: Appropriate Technology in Developing Countries, students ranging from first year to graduate level learned about some technologies in theory and others while physically constructing them. By introducing design projects, students can transform certain technologies and turn the design into reality, leading to greater retention of course content.

Another change relates to the need to overcome the constraint of few professors as well as funding problems that constrain the purchase of materials or development of new courses to improve learning outcomes for the program. During the development of the humanitarian engineering program, there have been times new course needs were not met by the department. In turn, the humanitarian engineering program has leaned on private donors, grant funds, and student affairs to provide support for training sessions, technical workshops, and hands on demonstrations to display the different components of practicing engineering throughout the world. One effective method of attaining funds has been to gear the program to have a positive and meaningful impact on the entire student body. Once a workshop is proved to benefit the 
campus, funds through student affairs were applied for and used to further the goals of the program. Several grants have also been won through the NSF, IEEE, and Rotary International through the ESS/EWB club to support student initiative in humanitarian engineering (see Table 3 ). There seems to be a trend in engineering to focus efforts toward marginalized communities and with that trend are funding opportunities that can be utilized. At ESF, we have been fortunate enough to be the recipient of some of these funds and have relied less heavily on the battle for limited university funds.

TABLE 3

RECENT PROGRAM GRANTS

\begin{tabular}{|l|l|c|}
\hline \multicolumn{1}{|c|}{ Funding Agency } & \multicolumn{1}{c|}{ Grant } & Amount \\
\hline National Science Foundation & CBET & $\$ 25,000$ \\
\hline Anchor QEA & Anchor QEA Foundation & $\$ 10,000$ \\
\hline Rotary International & Watertown, NY Chapter & $\$ 10,000$ \\
\hline Institute for Electrical and Electronics Engineers & IEEE Foundation Inc. & $\$ 10,000$ \\
\hline Rotary International & Rotary District 7090 & $\$ 4,000$ \\
\hline SUNY-ESF & Student Sustainability Fund & $\$ 1,000$ \\
\hline
\end{tabular}

A component that has worked well has been the pairing of engineering theory and engineering practice. It is important for students to be well versed in engineering principles; however, students may struggle to grasp the principles without any practical experience. This is where field courses such as ERE 311, the global dimension component of the NAE GCSP, and the ESS/EWB organization play a critical role. These opportunities give students the ability to see how engineering principles are practiced in different cultures and parts of the world.

\section{Case Studies/Successes Demonstrating Best Practices}

By integrating the five NAE GCSP components and the detailed best practices into coursework and hands on learning opportunities, the following experiences were completed within the ESF program:

1) Students in ERE 496: Humanitarian Engineering for Development Workers participated in a case study and conceptual design of latrines for a community in Senegal. Students spoke with volunteers living in Senegal and connected with the culture and ideologies of the community members. Being able to speak with current volunteers that shared cultural information shaped the engineering design produced by students based on technical guidance in the course text. In this way, students were able to learn concepts and theory, apply knowledge within a certain context, reflect on the given information and situation, and experiment with alternatives that may solve the problem.

2) A workshop was conducted where students built hydraulic ram pumps, biosand filters, UV water disinfection systems, and assembled a solar panel array. This was part of an active project led by the Global Youth Service Team on the Burma Thailand Border, which fueled students, knowing that the systems they were building were having an impact in a different part of the world. Within the same context, students participating in the program have built micro-hydro 
generators, as well as improved cook stoves and various types of water filters. The hands-on experience demonstrates the "do it" approach, allowing students to reflect on how important construction knowledge and skills are during projects.

3) Students inspired and supported by the program have had the opportunity to go above and beyond the ordinary college experience. A specific undergraduate student has been able to travel to Costa Rica twice, Peru three times, and Honduras and Panama once to further their knowledge of humanitarian engineering and to improve lives in the developing world. The same student has traveled the U.S. presenting the work he has completed within the program and has been successful in raising the funds necessary by using the program's support structure and principles.

\section{CONCLUSION}

Through their passion and motivation to improve the world using sustainable engineering, ESF students and faculty have planned, designed, built, and maintained a successful humanitarian engineering program. This program has evolved to fit into the limited resources offered by the small ESF College and the infinite spectrum of ambitions held by the students. It has succeeded by sending students into international development careers and delivering needed resources and relief to partner communities. The road to achieving these program outcomes has involved building courses, course lessons, student organizations, case studies, best practices, lessons learned, and relying on and learning from already established programs such as the NAE GCSP, EWB, and Engineering for Change, among many more. We hope that through sharing our program, similar outcomes can be realized at other small colleges or universities.

\section{REFERENCES}

1. NAE, Infusing Real World Experiences into Engineering Education, ed. N.A.o. Engineering. 2012, Washington, DC: National Academies Press.

2. Ambrose, S.A., Undergraduate Engineering Curriculum: The Ultimate Design Challenge The Bridge, 2013. 43 


\section{APPENDIX}

TABLE 4

ABBREVIATION DESCRIPTIONS

\begin{tabular}{|c|c|}
\hline Program & Description \\
\hline APO & $\begin{array}{l}\text { Alpha Phi Omega: A service based fraternity at ESF and Syracuse } \\
\text { University }\end{array}$ \\
\hline ASCE & American Society of Civil Engineers \\
\hline AWMA & Air and Waste Management Association \\
\hline AXS & Alpha Xi Sigma: A service based honor society at ESF \\
\hline CBET & $\begin{array}{l}\text { Division of Chemical, Bioengineering, Environmental and Transport } \\
\text { Systems }\end{array}$ \\
\hline EPA & Environmental Protection Agency \\
\hline ERE & Environmental Resources Engineering Department at ESF \\
\hline ESF & The College of Environmental Science and Forestry \\
\hline ESS & Engineering for a Sustainable Society \\
\hline EWB & Engineers Without Borders \\
\hline FOR & Course titles under the Forestry department at ESF \\
\hline GEO & Course titles under the Geography department at Syracuse University \\
\hline IEEE & Institute for Electrical and Electronics Engineers \\
\hline ISDE & International Sustainable Development Engineering \\
\hline NAE GCSP & National Academy of Engineering Grand Challenges Scholar Program \\
\hline NSF REU & National Science Foundation Research Experience for Undergraduates \\
\hline NYWEA & New York Water and Environment Association \\
\hline Operation Wallacea & An organization that runs worldwide student research programs \\
\hline
\end{tabular}




\section{Humanitarian Engineering Program}

State University of New York College of Environmental Science and Forestry

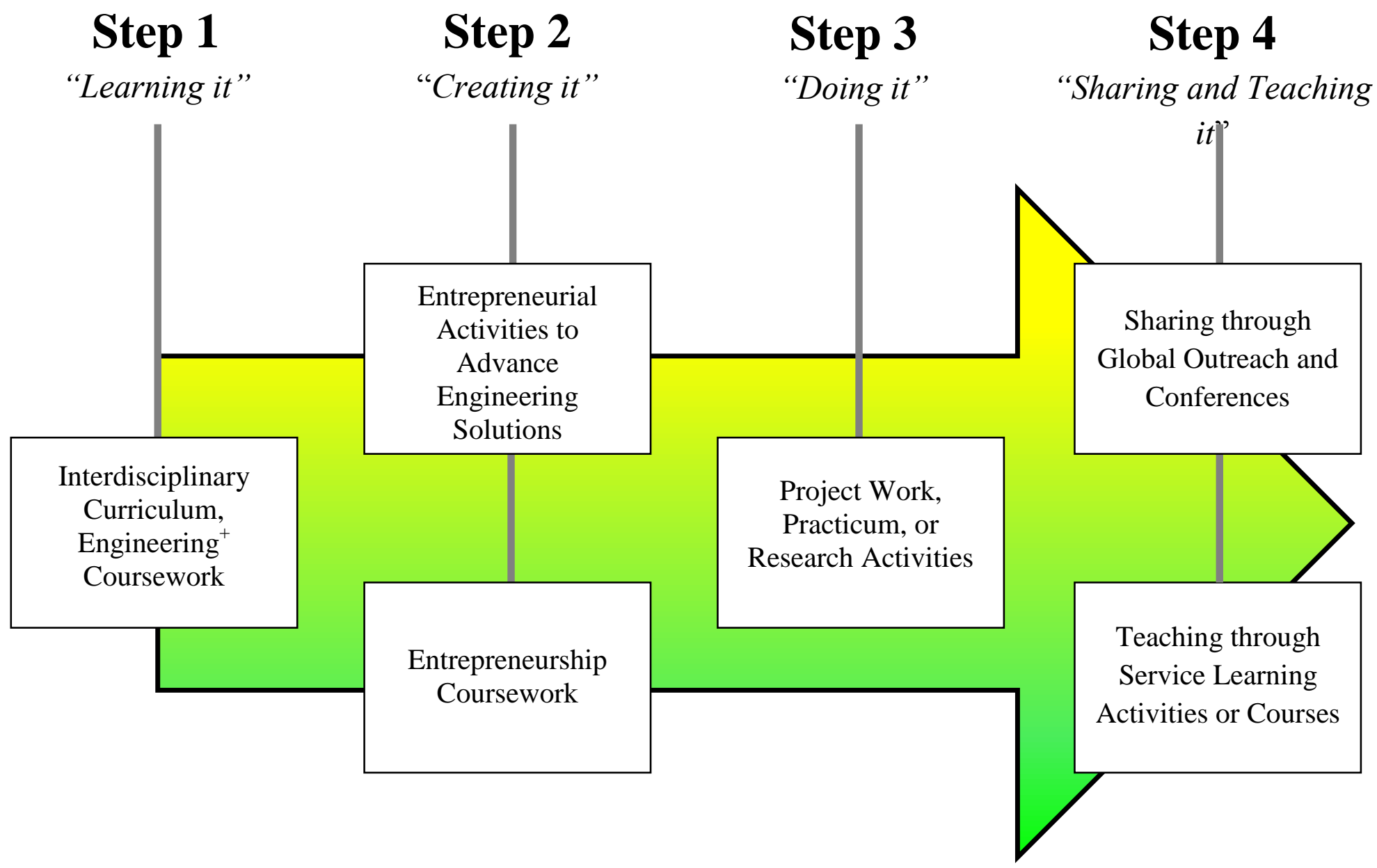

Where 'it' is one or more of the fourteen NAE grand challenges in engineering 
TABLE 5

RECENT STUDENT PROGRAM TRAVEL

\begin{tabular}{|c|c|c|}
\hline Year & Location & Description \\
\hline 2014 & Washington D.C. & $\begin{array}{l}2 \text { students attended the Engineers Without Borders National } \\
\text { conference }\end{array}$ \\
\hline 2014 & Honduras & $\begin{array}{l}2 \text { students worked in country to further a potable water } \\
\text { project started in } 2007\end{array}$ \\
\hline 2014 & Haiti & $\begin{array}{l}5 \text { students traveled to begin a sanitation and reforestation } \\
\text { project }\end{array}$ \\
\hline 2014 & South Africa & A student traveled to Cape Town to intern with Soil For Life \\
\hline 2014 & Nepal & $\begin{array}{l}\text { A student lived in Nepal and interned with the Kevin Rohan } \\
\text { Memorial Eco Foundation }\end{array}$ \\
\hline 2014 & India & $\begin{array}{l}\text { A student lived in India, interning within the water resources } \\
\text { field }\end{array}$ \\
\hline 2014 & Guatemala & $\begin{array}{l}3 \text { students traveled to begin a sanitation and hygiene project } \\
\text { through Engineers Without Borders }\end{array}$ \\
\hline 2014 & Costa Rica & A graduate student performed research at Rancho Mastatal \\
\hline 2014 & Panama & $\begin{array}{l}\text { A student completed a } 3 \text { credit course in Panama offered } \\
\text { through EWB and ASCE }\end{array}$ \\
\hline 2014 & California & $\begin{array}{l}\text { A student traveled to Long Beach to present at the Grand } \\
\text { Challenges - Great Solutions Conference }\end{array}$ \\
\hline 2013-2014 & Peru & $\begin{array}{l}\text { A student traveled three times to Peru to continue a rural } \\
\text { electrification project }\end{array}$ \\
\hline 2013-2014 & Jamaica & $\begin{array}{l}\text { A master's international student traveled to Jamaica to serve } \\
\text { in the Peace Corps }\end{array}$ \\
\hline 2013 & Costa Rica & $\begin{array}{l}12 \text { students traveled on behalf of the ERE } 311 \text { course hosted } \\
\text { through Rancho Mastatal }\end{array}$ \\
\hline 2013 & California & $\begin{array}{l}\text { A student traveled to San Jose to present at the Global } \\
\text { Humanitarian Technology Conference }\end{array}$ \\
\hline 2013 & Rutgers University & $\begin{array}{l}5 \text { students attended the Engineers Without Borders } \\
\text { Northeast Conference }\end{array}$ \\
\hline 2012 & Mexico & $\begin{array}{l}8 \text { students traveled to Chiapas to work on wetland } \\
\text { restoration and mycelium filtration }\end{array}$ \\
\hline 2012 & $\begin{array}{l}\text { University of } \\
\text { Pennsylvania }\end{array}$ & $\begin{array}{l}22 \text { students attended the Engineers Without Borders } \\
\text { Northeast Conference }\end{array}$ \\
\hline 2011 & Columbia University & $\begin{array}{l}12 \text { students attended the Engineers Without Borders } \\
\text { Northeast Conference }\end{array}$ \\
\hline 2011 & Honduras & $\begin{array}{l}5 \text { students traveled twice within } 2011 \text { to begin construction } \\
\text { on a potable water system }\end{array}$ \\
\hline
\end{tabular}

